\title{
Ownership, gender, and experience as correlates of policy implementation in the management of university libraries in the South-South, Nigeria
}

\author{
Jennifer Ngozi B. Igwela, Ph.D \\ University Librarian \\ Rivers State University \\ Port Harcourt, Nigeria \\ E-mail: blessing4okanu@yahoo.com \\ Cell: +2348063948870 \\ Ominini Brother Asako Walson, PhD \\ Department of Educational Management, \\ Faculty of Education \\ Ignatius Ajuru University of Education \\ Rumuolumeni, Port-Harcourt, Nigeria \\ E-mail:walsonomis@yahoo.com: \\ Cell: +2348038877492, +2348186691620
}

\begin{abstract}
The study examined ownership, gender and experience as correlates of policy implementation in the management of Universities Libraries in South-South, Nigeria. The correlational survey design was adopted for the study. Three (3) research questions and three (3) hypotheses guided the study. The population of the study was 1,465 which comprised 12 university librarians from the 12 State and Federal Universities in South-South, 263 other professional librarians and 1,200 year 3 students who are regular library users in the universities. The sample for the study was 385 respondents which consisted of 12 university librarians from the twelve universities, 263 other professional librarians and 120 years 3 students. The convenience sampling technique was used to select 10 year 3 students each from the 12 universities. Three instruments were used for data the collection namely: questionnaire, interview, and focus group discussion. The overall internal consistency reliability index of the questionnaire obtained through Cronbach's alpha estimate was 0.95 . The data collected were analyzed using mean and standard deviations for the research questions. The null hypotheses were tested using multiple regressions and associated t-test. The findings showed that in the management of university libraries in South-South Nigeria, library policies on main duties and responsibilities, user-oriented library concepts, schedule of duties, were highly implemented. On account of these findings, it was recommended among others that: The National Universities Commission (NUC) should monitor the implementation of the policy statements. This is to ensure that libraries irrespective of ownership, gender and experience of the librarians, are encouraged and supported to implement the policy statements to a very high extent.
\end{abstract}

Keywords: Ownership, Gender, Experience, Policy Implementation, Management, University Library, South-South, Nigeria

\section{Introduction}

The efficiency and effectiveness of library functions and services is determined by the extent to which policies are implemented by the management of libraries in universities. It is worth noting that library is the engine house of every academic institution in the society, especially the university community. It is the cardinal unit that strengthens the development of an individual, groups and the society at large via its rich and resourceful information generation and management. The strategic roles of the university library cannot be overemphasized. Every university relies on 
Jennifer Ngozi B. Igwela, Walson and Ominini Brother Asako: Ownership,gender, and experience as correlates of policy implementation in the management of university libraries in the South-South, Nigeria

the library, not just as an information custodian for its academic goals and objectives, but also as an organ for gathering and collecting information resources of all kinds and forms. The library assumes intellectual and physical control of such information resources, organizes them, manages and makes these resources available to its users. Hence the users of the library consume these information resources directly or indirectly to create more information through research and publication. Although information may be obtained outside the library, the processes are usually not very easy and the cost can be quite overwhelming. The special role of the library, therefore, is to enhance the process of retrieving information of whatever type, form and size. The university library, thus, has the special role of providing the place where researchers and members of the university community can quickly retrieve information in all fields, in an organized manner. This function requires money, large scale resources and expertise not available to the individual.The library is a defined organized entity, involving the collection of books and non-book materials used and maintained by a public body or a private individual and corporate bodies. It is an organized collection of resources made accessible to a defined community of users for reference or borrowing purposes (Mattson, 2000).

The university librarian performs dual responsibilities, as an academic staff and a professional manager of the library. The librarian is also the chief executive officer of the library, designated with the following professional duties such as: indexing services, binding of books and journals, consultancy services, compilation of abstracts and bibliographies, writing of biographies, cataloguing and classification and overseeing to the day to day running of the library. The administrative duties of the librarian include the management of library's financial, material and human resources. The financial matter embraces preparation of budget estimates for the library system, with inputs from the library departmental heads for submission to and defense before the senate estimate committee (National Universities Commission, (NUC), 1997).The disbursement of funds to the departmental libraries from the school budget is guided by the National Universities Commission (NUC) formula which is currently $60 \%$ for academic and $40 \%$ for operational costs. The librarian also allocates approved funds, establishes and keeps regular and accurate account records for income and expenditure, and ensures prompt returns on the grants to the source, the NUC, through the Vice Chancellor. Besides, the librarian procures materials in bulk like serials, stationary and cleaning materials. The librarian also plans strategies for internal revenue generation to upgrade or maintain his or her services beyond institutional financial resources and provision. Such services could include bindery, publishing, internet and consultancy services (Meyer, 1997). Finally, the librarian manages approved budget within the university accounting system, with particular respect to collection development, like subscription to serial publication on a standing order basis. This is to ensure that the library gets new and current serials which users need regularly to avoid stock out.

The librarian manages the library. Management in real practice includes accomplishment of certain defined activities with people. It means achieving the aims and objectives of any human group or organization. According to Heinz \& Harold (2005), management is often used as a synonym for related words like administration, leadership, ownership, power, decision-making, organization, and 
Jennifer Ngozi B. Igwela, Walson and Ominini Brother Asako: Ownership,gender, and experience as correlates of policy implementation in the management of university libraries in the South-South, Nigeria

control. But its main components remain planning, budgeting, scheduling, organizing, directing and controlling, measuring and evaluating. The university librarian performs all these management functions. Through these functions, the university is expected to implement the policy statements for the libraries.

The effective management of libraries relies on policies statements. Policy is a blue print that provides direction towards the achievement of goals. It is a course of actions adopted by a person, group of persons or government, or the set of principles on which they are based. Sule (2013) defined policy as a verbal, written or overall guide setting up boundaries that supply the general limits and direction in which administrative or managerial action takes place. Policy reveals an administrator's intentions for a period in the future and is decided in advance. It defines the area in which decisions are to be made, but it does not give the decisions. Dye, (1984) referred to policy as important events that provide directions to organizational activity. All these definitions indicate that the concept of policy is a goal-oriented behaviour instead of random chance behaviour. It also follows that policies are actions of organizations which may be different from what they do. Therefore, policy in this study implies actions expected of libraries to implement in order to achieve predetermined objectives through its various statement. These policy statements provide a way to judge the appropriateness of all potential activities the organization might engage in. Within the university system, the policy statements are contained in the manual provided by the National University Commission

The Manual on University Management (National Universities Commission, 1997) identified specific policy statements which a university library is expected to adopt and implement. They include: Policy on main duties and responsibilities of librarians, user-oriented library concept and schedule of duties.

Policy statements on the main duties and responsibilities specify the duties of the librarian in the university system which is collegial and relates objectives of the library. These duties as outlined in the Manual on University Management (National University Commission, 1997) are: reporting mechanism to the ViceChancellor on measures to providing user satisfactory services. The measures include: acquisition and development, strategic planning and budgeting, formation of state, regional, national and international partnership.

The user-oriented library concept in university libraries indicates that university librarian should aim at developing a user friendly library. The library resources and services are primarily for users. This means that whatever is done in the library should be based on the information needs of the users. This is because the term user-centered or user-oriented is associated with the increased attention to the needs of users of the system.

The policy on the schedule of duties states that the university librarian is the head of the university library and leader of the team. Therefore, the librarian should practice participatory management, encouraging communication horizontally and vertically through regular meetings. The librarian should administer the library and perform related library services, work in a variety of settings, and set up or work with databases and information systems to catalogue and access information.

It is very pathetic however to note that since the formulation of the national policy on education, its implementation as relates to library and the development of librarians has not been given expected 
Jennifer Ngozi B. Igwela, Walson and Ominini Brother Asako: Ownership,gender, and experience as correlates of policy implementation in the management of university libraries in the South-South, Nigeria

treatment. Research has shown that these policies had been implemented more on paper than in practice. To buttress this point, Nok (2006)observed that the statutory $10 \%$ of the recurrent votes of tertiary education institution which should be set aside for library development was honored more in disobedience rather than compliance.

Implementation is the operational stage where the original goals of the policy are actually translated into concrete actions and results (Uduomoh \& Okoro, 2007); and this has been found to be the most problematic (Ugwu, 2000). The translation of policy statements into practice, which is the implementation, is of great importance to every library. Corrado (2005) described policy implementation as the process of executing set policies made at the higher level of management into practice for a workable system. Policy implementation therefore is the act of translating set of policies made by higher authorities into action by subordinates charged with technical, managerial and administrative task. Evidence has shown that the problem of policy implementation is not lack of effective policy, but the dearth of political will to implement them (Okoroafor, 2006). This is evident in various sectors or institutions in the country's educational system and affects library management (Odukoya, 2012).

A critical look at university libraries in South-South, Nigeria showed that there is paucity of funds to provide needed resources to meet the needs of users. Library stock are almost becoming obsolete, students continually complain of the poor services provided in the libraries, library infrastructure are aging daily, there is epileptic power supply to enable usersget some of their information needs photocopied. Okiy (2005) noted, maintenance is not carried out in libraries and the facilities are decaying daily. Most users also complain of high charges paid for the use of these libraries in the name of generating funds yet the services provided are still dismal. All these may be due to the poor level of policy implementation in the library which may be due to ownership of the university.

Universities are either owned by the Federal or State governments or individuals or corporate bodies. Federal universities are those owned and managed by the federal government. State universities are those owned and managed by state governments. Private universities are those owned and managed by individuals or corporate bodies. In spite of the differences in ownership, the National Universities Commission accredits and regulates all the academic programmes of universities. Each library in federal, state or private university is managed accordingly by their respective librarians who implement the various policy statements. Ownership, gender, and experience could be some of the factors that mediate policy formulation and implementation. The correlates of the extent of implementation of policies in the management of university libraries should be a subject of concern for verification.

For librarians to efficiently and effectively implement library policies in the management of university libraries, it is presumed that demographic factors could be essential. In the Nigeria setting, according to Ibukun (2011), demographic factors like gender, and experience have been considered in the appointment of the right caliber of individuals into managerial positions (librarians inclusive) with the believe that these factors would make some individuals to be more effective than others.

Gender is described as the characteristics between males and females in any society. Gender, according Ezeh, (1997) refers to the differentiation in roles between men and women which is different from sex but construed by society through 
Jennifer Ngozi B. Igwela, Walson and Ominini Brother Asako: Ownership,gender, and experience as correlates of policy implementation in the management of university libraries in the South-South, Nigeria

socialization. Sex is the physical difference between a people's body e.g. boy or girl. Gender which is the behavioural, cultural or psychological traits is typically associated with one's sex. A person's gender role refers to the way a community defines what it is to be a woman or a man. Each community expects a woman and man to look, think, feel and act on certain ways just because they are women or men. In most countries for example, women are expected to prepare food, fetch water and care for children while men are expected to work outside the home to provide for their families and parents and defend them from harm. There are contrasting views over which gender performs better in management of things in the society. This work seeks to contribute in resolving this controversy on gender as it affects librarians' effective and efficient implementation of library policy statements in the management of university libraries.

Experience is the number of years a person has done a job. Studies conducted by Walson (2015) showed that experience predicted the performance of principals in secondary schools in some task areas. This indicates that experience may be related to performance. However, Achunine (1998) opined that the length of time one stays on a job does not necessarily make one efficient; and argued that professional training is a more important factor than on-the-job experience in an administrator's job performance. It is therefore important to determine the extent experience relates to librarians' effective and efficient implementation of library policy statements of the National Universities Commission in the management of university libraries.

The need to examine the relationship between these variables and library policies implementation in the management of university libraries becomes inevitable considering contrasting views of scholars on their relationship with performance. There is therefore, the need to examine ownership, gender, and experience as correlates of the extent library policy statements are implemented in the management of university libraries in South-South, Nigeria.

\section{Statement of the problem}

It has been observed that many students do not patronize the library owing to poor quality service provided. Most libraries in universities in the South-South, Nigeria have challenges in promoting teaching and research which are the roles of tertiary education. This position is probably a fallout of implementation of library policies in the universities. The policy statements are in respect of main duties and responsibilities of the university librarian, user-oriented library concept, schedule of duties, collection development, funds allocation and management, maintenance culture, information marketing, and computer competence. The implementation of the policy statements will translate word into actions in the management of university libraries. This will equip them with the resources and processes required to position the libraries to attain their objectives.

The extent to which these library policies are implemented in the management of university libraries in South-South Nigeria has not been determined. Although, studies have been carried out on the different aspects of management of university libraries, no study, to the knowledge of the researcher, has been done on the correlates of the extent of implementation of the policy statements of the National Universities Commission in the management of university libraries in SouthSouth, Nigeria. To this effect, the problem of the study is: ownership, gender, and experience as correlates of the extent the National Universities Commission's policy statements are implemented in the 
Jennifer Ngozi B. Igwela, Walson and Ominini Brother Asako: Ownership,gender, and experience as correlates of policy implementation in the management of university libraries in the South-South, Nigeria

management of university libraries in SouthSouth, Nigeria?

\section{Purpose of the study}

The major purpose of the study is to determine the extent ownership, gender, and experience relate with library policy implementation in the management of university libraries in the South-South, Nigeria. Specifically, the study seeks to determine the extent ownership, gender and experience relate with library policy implementation in the management of university libraries with respect to: Main duties and responsibility of the librarians, User oriented library concept and, schedule of duties.

\section{Research questions}

The following research questions were posed to guide the study:

1. What is the extent to which the policy on main duties and responsibilities of university librarians is implemented in the management of university libraries?

2. What is the extent of policy implementation of user-oriented library concept in the management of university libraries?

3. What is the extent to which the policy on schedule of duties is implemented in the management of university libraries?

\section{Hypotheses}

The following null hypotheses were formulated and tested at 0.05 level of significance:

H0 $0_{1}$ There is no significant relationship between ownership, gender, experience of librarians and library policy implementation on main duties and responsibilities in the management of university libraries.

$\mathbf{H O}_{2}$ : There is no significant relationship between ownership, gender, experience of librarians and library policy implementation on useroriented library concept in the management of university libraries.

H0 $_{3}$ : There is no significant relationship between ownership, gender, experience of librarians and library policy implementation on schedule of duties in the management of university libraries;

\section{Methods}

The study adopted correlational survey design. The study was carried out among some selected state and federal university libraries in the South-South geopolitical zone of Nigeria. The states in the zone comprise Akwa Ibom, Bayelsa, Cross River, Delta, Edo and Rivers. The South-South Zone of Nigeria falls within the Niger Delta Region whose climate varies from the hot equatorial forest type on the Southern lowlands to the humid tropical in the northern highlands and the cold mountain type in the Obudu Plateau area.

The population of the study was 1,465 which comprised 12 librarians from the 12 State and Federal University Libraries in South-South Nigeria, 253 other professional librarians and 1,200 year 3 students who have stayed long enough in the universities and are regular library users from the Universities. The final year students were not used for the study because they were very busy with their project work and could not spare the researcher adequate time and attention to provide information required for the research.

The sample for the study was 385 respondents which consisted of all 12 university librarians from the twelve universities, all 253 other professional librarians and 120 year 3 students. Convenience sampling technique was used to sample 10 year three students each from the 12 universities. No sampling was done for the university librarians and other 
Jennifer Ngozi B. Igwela, Walson and Ominini Brother Asako: Ownership,gender, and experience as correlates of policy implementation in the management of university libraries in the South-South, Nigeria

professional librarians because of the small number that could be managed.

The researcher used questionnaire, interview schedule and focus group discussion to collect relevant information from the respondents.

The instruments were validated by three experts, one in the Educational Administration and Planning, one in Library and Information Science, one in Measurement and Evaluation all in the Faculty of Education, University of Nigeria, Nsukka, Out of the 265 copies of the questionnaire (OGECPIMULQ)) administered to the university librarians and 253 professional librarians, 259 were correctly filled and used for analysis, while six copies were not correctly filled, as such expunged from analysis. However, the interviews were conducted using the university librarians, while the focus group discussion was conducted using the students with the help of the three assistants who served as a moderator and note takers at each discussion. The focus group discussion has 12 groups comprising five in each group

The data collected with the questionnaire were analyzed using Mean Scores and Standard Deviation in answering the research questions. The real limits of numbers, 3.50-4.00 = Very High Extent (VHE), 2.50-3.49 = High Extent (HE), 1.50-
2.49= Low Extent (LE), and 1.00-1.49= Very Low Extent (VLE), were used to interpret the results. The standard multiple regression and associated t-test were used to test the null hypotheses at 0.05 level of significance. This was computed using the statistical package for social science (SPSS) software version 21 . The variables were dummy coded as follows: Ownership: Federal $=1$, State $=2$; Gender $=$ Male $=1$, Female - 2. Meanwhile, experience measured in years was entered as a continuous variable in the regression model. A null hypothesis was not rejected if the probability value is greater than .05 , but rejected if the probability value is less than .05The data from face-to-face interview with the university librarians and focus group discussion with the students were transcribed and analyzed qualitatively.

\section{Results}

The findings of the data analyzed are presented according to the research questions and hypotheses that guided the study.

Research question 1: What is the extent to which the policy on main duties and responsibilities of university Librarians is implemented in the management of university libraries?

Table 1: Means ratings on the extent the policy on main duties and responsibilities of university librarians is implemented in the management of university libraries $(n=259)$

\begin{tabular}{clccl}
\hline S/N & Question items (main duties) & $\bar{X}$ & SD & DEC \\
\hline 1 & There are clearly stated goals for the library & 3.59 & .63 & VHE \\
$* 2$ & There are no clearly stated objectives for the library & 2.65 & .99 & $\mathrm{HE}$ \\
3 & The strategies for achieving objectives are clear & 2.92 & .81 & $\mathrm{HE}$ \\
$* 4$ & User satisfaction is not the major concern of the librarian & 2.59 & 1.03 & $\mathrm{HE}$ \\
5 & The librarians main duty is to provide library resources and & 3.10 & .88 & $\mathrm{HE}$ \\
& services in the library & & & \\
$* 6$ & The performance of the library is not assessed regularly & 2.67 & .96 & $\mathrm{HE}$ \\
& Cluster mean & 2.76 & .88 & $\mathrm{HE}$ \\
\hline
\end{tabular}

VHE $=$ Very High extent, HE $=$ High Extent, ${ }^{*}$ Negative items scored in the reverse order

Table 1 reveals that all the items from 1-6

had high mean scores. Item 1 had a mean

Journal of Library Services and Technologies, Volume 2 Number 2, 2020 
Jennifer Ngozi B. Igwela, Walson and Ominini Brother Asako: Ownership,gender, and experience as correlates of policy implementation in the management of university libraries in the South-South, Nigeria

score of 3.59 and standard deviation of .63 . This means that stated goals for the library are clear to a very high extent. Item 2 had a mean score of 2.65 and standard deviation of .99 . This shows that the respondents are of the opinion that stated objectives for the library are clear to a high extent. Item 3 had a mean score of 2.92 and standard deviation of .813. This means that the strategies for achieving the objectives are clear to a high extent. Item 4 had a mean score of 2.59 and standard deviation of 1.03. This means that user satisfaction is the major concern of the librarian to a high extent. Item 5 had a mean score of 3.10 and standard deviation of .88 . This shows that the librarian main duty which is to provide library resources and services in the university library is implemented to a high extent. Item 6 had a mean score of 2.67 and standard deviation of .96. This means that the policy on regular assessment of the performance of the library is implemented to a high extent. The cluster mean and standard deviation were 2.75 and .883 respectively. These indicate that the policy on main duties and responsibilities of university librarians is highly implemented in the management of university libraries in South-South, Nigeria. However, while clearly stated goal is the most implemented policy statement, user-satisfaction is the least implemented.

The interview responses given by the university librarians on main duties and responsibilities were recorded as follows:

a) Some of the objectives were provision of information to staff and students of the university for teaching, research, assignments and projects and that they were communicated to other library staff

b) Some of the strategies were provision of relevant books, eresources, journals, etc., provision of conducive reading environment and provision of adequate staff support to assist library users on how to obtain the needed information in the library

From the focus group discussion with students on main duties and responsibilities of the university librarians, the following were deciphered:

a) It was reported that the librarian had provided basic amenities needed for academic performance such as vase textbooks, conducive environment, basic technology competence for Research and Development (R\&D)

b) It was reported that with regard to the library stock acquisition which was based on tertiary intuition fees, support to the growth of the library, patronage and adherence to the library rules and regulations were some of the notable inputs made

These findings corroborate with the interview and focus group discussion with librarians and students respectively. The librarians in the universities during the interview stated that the objectives of the library in the management of university libraries were to: provide relevant library stocks which are needed by the students, provide information to staff and students of the University Teaching, research, assignment and projects. The librarians also stated that library objectives are communicated to other library staff for better understanding to serve as guide in the performance of their duties. On some of the strategies used for achieving the objectives of the libraries, the librarians stated that they provide library resources (books, journals, ande-material,) by acquiring, processing and placing them systematically on the shelves for easy access and retrieval. They also provide conducive reading environment for library users, and provide adequate staff support to assist library users on how to obtain needed information in the library. On focus group discussion with students on the ways librarians provide resources and 
Jennifer Ngozi B. Igwela, Walson and Ominini Brother Asako: Ownership,gender, and experience as correlates of policy implementation in the management of university libraries in the South-South, Nigeria

services for them showed that the librarians direct the students where to get needed books they want to read, and where to keep their bags for security purposes. On whether they make input for library stock acquisition, the students said they do not make much input in the library in the process of stock acquisition.

Research question 2: What is the level of policy implementation on user oriented library concept in the management of university libraries?

Table 2: Mean ratings on the level of policy implementation on user-oriented library concept in the management of university libraries $(n=259)$

\begin{tabular}{|c|c|c|c|c|}
\hline $\mathbf{S} / \mathbf{N}$ & Question ttems (User oriented library concept) & $\bar{X}$ & SD & DEC \\
\hline 7 & Collection development is based on information needs of the users & 3.06 & .81 & $\mathrm{HE}$ \\
\hline$* 8$ & Our university library is not user friendly & 3.28 & .71 & $\mathrm{HE}$ \\
\hline 9 & Library resources services are made available to the users & 3.20 & .70 & $\mathrm{HE}$ \\
\hline$* 10$ & $\begin{array}{l}\text { Users select the materials they need in their special subject areas } \\
\text { guided by the librarian }\end{array}$ & 2.98 & .83 & $\mathrm{HE}$ \\
\hline 11 & $\begin{array}{l}\text { Our library focuses on access rather than ownership of information } \\
\text { sources }\end{array}$ & 2.95 & .74 & $\mathrm{HE}$ \\
\hline$* 12$ & $\begin{array}{l}\text { Generalized and massive library collections that are costly are de- } \\
\text { emphasized }\end{array}$ & 2.56 & .88 & $\mathrm{HE}$ \\
\hline \multirow[t]{2}{*}{13} & $\begin{array}{l}\text { Information and communication technology (ICT) is used to access } \\
\text { information on the library }\end{array}$ & 3.06 & .79 & $\mathrm{HE}$ \\
\hline & Cluster mean & 3.01 & 0.78 & $\mathrm{HE}$ \\
\hline
\end{tabular}
$\mathrm{HE}=$ High Extent, DEC= Decision; * Negative items scored in the reverse order

Table 2 shows that all the items from 7-13 had high mean scores. Item 7 had a mean score of 3.06 and standard deviation of .81 . This means that collection development is based on information needs of the users to a high extent. Item 8 had a mean score of 3.28 and standard deviation of .71. This means that university libraries in south-south Nigeria are user friendly to a high extent. Item 9 had a mean score of 3.20 and standard deviation of .70. This means that library resources and services are made available to the users to a high extent. Item 10 had a mean score of 2.98 and standard deviation of .83. This means that users select the materials they need in their special subject area guided by the librarian to a high extent. Item 11 had a mean score of 2.95 and standard deviation of .74. This means that university libraries in south-south Nigeria focus on access rather than ownership of information sources. Item 12 have a mean score of 2.56 and standard deviation of .88 . This means that generalized and massive library collections that are costly are not emphasized to a high extent. Item $13 \mathrm{had}$ a mean score of 3.06 and a standard deviation of .79. This means that Information and Communication Technology (ICT) is used to access information in the libraries to a high extent. The cluster mean and standard deviation of 3.01 and .78 respectively indicated that the extent of policy implementation of user oriented library concept in the management of University libraries in south-south Nigeria is high. The policy on the user-friendly is the most implemented, while that on massive library collections that costly is least implemented.

The interview responses given by the university librarians on user's oriented library concept were recorded as follows:

a) It was reported that library's orientation and user's instructions 
Jennifer Ngozi B. Igwela, Walson and Ominini Brother Asako: Ownership,gender, and experience as correlates of policy implementation in the management of university libraries in the South-South, Nigeria

were the steps taken to guide users in selecting materials they need.

b) It was reported that ICT was used to access information, and through OPAC and subscription to databases (e-library and pro quest) which is also part of the plans to library automation.

From the focus group discussion with students on user's oriented library concept of the university librarian, the following were deciphered:

It was reported that conducive environment for reading was one way the library was user friendly, although, there was need for improvement.

These findings are in agreement with the results of the interview and focus group discussion with Librarians and students respectively. The librarians during the interview stated that the steps taken to guide library users in selecting material in the library are through library orientation and user instruction library guide. On whether ICT is used to access information in the library and plans to ensure that the libraries are fully automated, the librarians stated that ICT gadgets are used to access library resources, which ensure that the libraries are automated is through Online Public Access Catalogue (OPAC) and subscription to Database (e-library which deals e-books, and Pro quest which deals with e-journals. On focus group discussion with students on what ways the is library is user friendly, the students stated that the library is user friendly because it provides the enabling environment for access to information and a conducive place for reading and research.

Research question 3: To what extent is the policy on schedule of duties implemented in the management of university libraries?

Table 3: Mean ratings on the extent policy on schedule of duties is implemented in the management of university libraries $(n=259$

\begin{tabular}{|c|c|c|c|c|}
\hline \multirow[t]{2}{*}{$\mathbf{S} / \mathbf{N}$} & \multirow[t]{2}{*}{ Question Items (Schedule of Duties) } & \multirow[t]{2}{*}{$\bar{X}$} & \multirow[b]{2}{*}{ SD } & \multirow[b]{2}{*}{ DEC } \\
\hline & & & & \\
\hline 14 & $\begin{array}{l}\text { The librarian is recognized as the head of the } \\
\text { university library system }\end{array}$ & 3.61 & .58 & VHE \\
\hline 15 & The librarian is seen as the leader of a team & 3.38 & .62 & $\mathrm{HE}$ \\
\hline 16 & There are regular staff meetings of all library staff & 2.79 & .88 & $\mathrm{HE}$ \\
\hline 17 & $\begin{array}{l}\text { Staff meetings involve both management and non- } \\
\text { management staff }\end{array}$ & 2.64 & .98 & $\mathrm{HE}$ \\
\hline 18 & Duties are allocated to all senior staff individually & 2.83 & .83 & $\mathrm{HE}$ \\
\hline 19 & Duties are allocated to staff as a team & 2.63 & .86 & $\mathrm{HE}$ \\
\hline \multirow[t]{2}{*}{20} & $\begin{array}{l}\text { Library staff are provided with schedule of duties } \\
\text { for guidance }\end{array}$ & 2.90 & .82 & $\mathrm{HE}$ \\
\hline & Cluster mean & 2.97 & .79 & $\mathrm{HE}$ \\
\hline
\end{tabular}

VHE = Very high extent, HE, High Extent, DEC $=$ Decision

Table 3 revealed that items 14-20 had high mean scores. Item 14 had a mean score of 3.61 and standard deviation of .58. This shows that the librarian is recognized to a very high extent as the head of the university library system. Item 15 had a mean score of
3.38 and standard deviation of .62. This means that the librarian is seen as the leader of a team to a high extent. Item 16 had a mean score of 2.79 and standard deviation of .88. This shows that the policy on regular staff meetings of all library staff is implemented to a high extent. Item 17 had a 
Jennifer Ngozi B. Igwela, Walson and Ominini Brother Asako: Ownership,gender, and experience as correlates of policy implementation in the management of university libraries in the South-South, Nigeria

mean score of 2.64 and standard deviation of .98. This means that staff meetings involving both management and nonmanagement staff are held to a high extent. Item 18 had a mean score of 2.83 and standard deviation of .83 . This shows that duties are allocated to a high extent to all the senior staff individually. Item 19 had a mean score of 2.63 and standard deviation of .86 . This shows that duties are allocated to staff as teams to a high extent. Item 20 had a mean score of 2.90 and standard deviation of .82. This means that library staff is provided to a high extent with schedule of duties for guidance. The cluster mean and standard deviation were 2.97 and .79 respectively. These indicated that the extent the policy on schedule of duties is implemented in the management of state and federal university libraries is high. The recognition of the librarian as the head of the library system is the most implemented, while allocating duties to staff is the least implemented.

The interview responses given by the university librarians on schedule of duties were recorded as follows:

a) It was reported that the university librarian was the head of the library and also in charge of the library

b) The modes of disseminating information to other librarians were given to be through memos to meetings, circulars, phone calls and text messages

c) The schedules of duties, according to the response was that, with respect to different sections, sectional heads were assigned

From the focus group discussion with students on schedule of duties of the university librarian, the following were deciphered:

It was reported that orderliness in library, building maintenance, technological competence and maintenance of the library environment proved that the university librarian was in charge.

These findings corroborate with the results from the interview and focus group discussion with librarians and students. During the interview with university librarians, they stated that the librarian is the head of the library that is in charge of the library by coordinating the various sections. On the modes of dissemination of information to other librarians, the librarians stated that they use text massages, circulars, and phone calls to converge meeting of library staff. On what are the schedules of duties to librarians in the library, the librarians stated that the various sections in the library has sectional heads and other subordinates for proper control, delegation of duties, and reporting. The focus group discussion with students on what makes them feel that the librarian is in charge, revealed that the orderliness in the library showed that the university librarians are carrying out their duties as expected, hence they are in full control.

Ho: There are no significant relationships between ownership, gender and experience of the librarians and the extent to which the policy statements on the main duties and responsibilities of the university are implemented in the management of university libraries. 
Jennifer Ngozi B. Igwela, Walson and Ominini Brother Asako: Ownership,gender, and experience as correlates of policy implementation in the management of university libraries in the South-South, Nigeria

Table 4: t-test on the implementation of policy on main duties and responsibilities of librarians

\begin{tabular}{|c|c|c|c|c|c|}
\hline \multirow[t]{2}{*}{ Model } & \multicolumn{2}{|c|}{ Unstandardized Coefficient } & \multirow{2}{*}{$\begin{array}{l}\text { Standard } \\
\text { Coefficient } \\
\text { Beta }\end{array}$} & \multirow{2}{*}{$\mathbf{t}$} & \multirow{2}{*}{ Sig } \\
\hline & $\mathbf{B}$ & Standard Error & & & \\
\hline Constant & 2.52 & .22 & & & .00 \\
\hline Ownership & .20 & .07 & .17 & 2.74 & .01 \\
\hline Gender & .13 & .07 & .12 & 1.87 & .06 \\
\hline Experience & .02 & .01 & .18 & 2.88 & .00 \\
\hline
\end{tabular}

$F$-value $=7.87, R$ - Square $=0.09, R$ - Square Change $=0.09$

Data on Table 4 show that the t-values for ownership, gender and experience are -2.74 $(\mathrm{p}=.01), 1.87 \quad(\mathrm{p}=.06)$ and $2.88 \quad(\mathrm{p}=.00)$ respectively. Therefore, ownership and experience are significantly related $(\mathrm{p}<.05)$ to the extent the policy statements on main duties and responsibilities of librarians are implemented. Librarians in Federal universities and those with more years of experience implemented these policies to a greater extent than those in state universities and those with less years of experience.

$\mathrm{Ho}_{2}$ : There are no significant relationships between ownership, gender and experience of the librarians and the extent to which the policy statements on user-oriented library concept are implemented in the management of university libraries.

Table 5: t-test on the implementation of policy on user oriented library concept

\begin{tabular}{llllll}
\hline Model & \multicolumn{2}{l}{ Unstandardized Coefficient } & $\begin{array}{l}\text { Standard } \\
\text { Coefficient } \\
\text { Beta }\end{array}$ & t & Sig \\
& B & Standard Error & & 16.62 & .00 \\
Constant & 3.23 & .20 & .17 & 2.52 & .01 \\
Ownership & 16 & .06 & .07 & -1.04 & .30 \\
Gender & -.06 & 06 & .15 & -2.37 & .02 \\
Experience & -.01 & 00 &
\end{tabular}

$F$-value $=5.73, R$ - Square $=0.06, R$ - Square Change 0.06

Data on Table 5 show that the t-values for ownership, gender and experience are 2.52 $(\mathrm{p}=.01),-1.04 \quad(\mathrm{p}=.30)$ and $-2.37 \quad(\mathrm{p}=.02)$ respectively. Therefore, ownership and experience are significantly related $(\mathrm{p}<.05)$ to the extent the policy on user-oriented library concept are implemented. Librarians in state universities and those with less years of experience implemented these policies to a greater extent than those in federal universities and those with more years of experience.

Ho3: There are no significant relationships between ownership, gender and experience of the librarians and the extent to which the policy statements on schedule of duties are implemented in the management of university libraries. 
Jennifer Ngozi B. Igwela, Walson and Ominini Brother Asako: Ownership,gender, and experience as correlates of policy implementation in the management of university libraries in the South-South, Nigeria

Table 6: $t$ test on the implementation of policy on Schedule of duties

\begin{tabular}{llllll}
\hline Model & \multicolumn{2}{l}{ Unstandardized Coefficient } & $\begin{array}{l}\text { Standard } \\
\text { Coefficient } \\
\text { Beta }\end{array}$ & $\mathbf{t}$ & Sig \\
& B & Standard Error & & 13.82 & .00 \\
Constant & 2.82 & .20 & .15 & 2.18 & .03 \\
Ownership & .14 & .07 & .18 & -2.69 & .01 \\
Gender & -.17 & .06 & .11 & 1.73 & .09 \\
Experience & .01 & .01 & F-value $=3.62, R$ - Square $=0.04$, R-Square Change $=0.04$
\end{tabular}

Data on Table 6 show that the t-values for ownership, gender and experience are 2.18, $(\mathrm{p}=.03),-2.69(\mathrm{p}=.01)$ and $1.73(\mathrm{P}=.09)$ respectively.Therefore, ownership and gender are significantly related $(\mathrm{p}<.05)$ to the extent the policy statements on schedule of duties of librarians are implemented. Librarians in state universities and male librarians implemented these policies to a greater extent than those in federal universities and the female librarians.

Table 7: $t$ test on the implementation of policy on Schedule of duties

\begin{tabular}{|c|c|c|c|c|c|}
\hline \multirow[t]{2}{*}{ Model } & \multicolumn{2}{|c|}{ Unstandardized Coefficient } & \multirow{2}{*}{$\begin{array}{l}\text { Standard } \\
\text { Coefficient } \\
\text { Beta }\end{array}$} & \multirow{2}{*}{$\mathbf{t}$} & \multirow{2}{*}{ Sig } \\
\hline & B & Standard Error & & & \\
\hline Constant & 2.82 & .20 & & 13.82 & .00 \\
\hline Ownership & .14 & .07 & .15 & 2.18 & .03 \\
\hline Gender & -.17 & .06 & .18 & -2.69 & .01 \\
\hline Experience & .01 & .01 & .11 & 1.73 & .09 \\
\hline
\end{tabular}

Data in Table 7 show that the t-values for ownership, gender and experience are 2.18, $(\mathrm{p}=.03),-2.69(\mathrm{p}=.01)$ and $1.73(\mathrm{P}=.09)$ respectively.Therefore, ownership and gender are significantly related $(\mathrm{p}<.05)$ to the extent the policy statements on schedule of duties of librarians are implemented. Librarians in state universities and male librarians implemented these policies to a greater extent than those in federal universities and the female librarians.

\section{Discussion}

Discussions were presented in accordance with the purposes of the study (research questions posed and hypotheses formulated).

Extent to which policy statements on main duties and responsibilities of university libraries is implemented

Based on the findings on research question one the respondents were of the view that there are stated goals for the library and the strategies for achieving the goals are clear. Respondents were also of the view that user satisfaction is the major concern of the librarian; the librarian's duty is to provide library resources and services in the library and that the performance of the library is regularly assessed. The respondents were of the view that the policy on main duties and responsibilities of the librarians is highly implemented in the management of university libraries in south-south Nigeria.

These findings are consistent with the views of Darinson (2013) who stated that the ideal duty and responsibilities of the university librarian is that of collegial, 
Jennifer Ngozi B. Igwela, Walson and Ominini Brother Asako: Ownership,gender, and experience as correlates of policy implementation in the management of university libraries in the South-South, Nigeria

development and strategic vision while successfully implementing operational details and managing staff. The findings also corroborate with the position of the Association of Research Libraries (ARL, 2016) that the university librarian as the executive administrator of the university library, has the following duties and responsibilities: acquisition of materials for the libraries in the universities.

The findings also agree with those of Harbo and Hanson (2012) who maintained that one major duty of the librarian is to provide services for the satisfaction of users and that if libraries want to improve the way they serve their users' needs, they must innovate their services.

The result of the test of hypothesis showed that ownership and experience are significantly related to the extent the policy statements on main duties and responsibilities of librarians are implemented. Librarians in Federal universities and those with more years of experience implemented these policies to a greater extent than those in state universities and those with less years of experience. Librarians in federal universities may have better working conditions predisposing them to perform their duties and responsibilities better. Those who have more experience are better prepared to perform their duties.

Extent to which policy on user-oriented library concept of university libraries implemented

The findings on this research question revealed that the extent of implementation of policy statements on user-oriented library concept in the management of university libraries was high. Specifically, the findings revealed that collection development is based on information needs of the users; and that university library is user friendly. It was also revealed that library resources and services are made available to the users; and the librarians guide users in selecting the materials they need in their specific subject areas, while the library focuses on access rather than ownership of information sources. The findings further showed that generalized and massive library materials that are costly are de-emphasized; while information and communication technology ICT are used to access information in the library. These findings agreed with the views of Harbo and Hanson (2012) who stated that library resources and services which are meaningful to the users instead of those traditionally useful to the library should be provided by the Librarians to enable users make maximum use of the library.

The result of the test of hypotheses showed that ownership and experience are significantly related to the extent the policy on user oriented library concept is implemented. Librarians in state universities and those with less years of experience implemented these policies to a greater extent than those in federal universities and those with more years of experience. This is not surprising because librarians in state universities and those with less experience are younger librarians who see libraries as serving in the main, the needs or the learners.

Extent of implementation of policy statements on schedule of duties in the management of libraries

The findings on this research question revealed that the extent to which policy statements on schedule of duties are implemented in the management of university libraries is high. Specifically, it was found out that the librarian who is the head of the university library system is seen as the leader of a team. This finding agreed with the assertion of Muhammad (2006) that the university librarian is the executive head of the university library who manages the

Journal of Library Services and Technologies, Volume 2 Number 2, 2020 
Jennifer Ngozi B. Igwela, Walson and Ominini Brother Asako: Ownership,gender, and experience as correlates of policy implementation in the management of university libraries in the South-South, Nigeria

human and material resources in the library by ensuring that library materials are provided in the right quality and quantity to meet the needs of users. It was also revealed that there are regular staff meetings of all library staff involving all management and non-management staff. Other findings include that duties are allocated to all senior staff individually and as teams, and that library staff are provided with schedules of duties for guidance. These findings are in agreement with the view of Darinson (2013) that schedule of duties of library staff is used to coordinate the activities of the library staff and students to ensure that needed materials and access to the materials is provided as at when due. The result of the test of hypotheses further showed that ownership and gender are significantly related to the extent the policy statements on schedule of duties of librarians are implemented. Male librarians and librarians in state universities implemented these policies to a greater extent than those in federal universities and female librarians. Therefore, male librarians and those in state universities appear to be more democratic in their administrative style than female librarians and those in the federal universities.

\section{Conclusion}

The study concluded that the implementation of policy statements by the university librarians in both federal and state university libraries was high extent. However, the level of implementation was dependent on ownership, gender and experience.

\section{Recommendations}

Based on the findings of the study and various implications which have been highlighted, the following recommendations are made:
1. More efforts should be made in the implementation of library policies on main duties and responsibilities of librarians, user-oriented library concepts and schedule of duties.

2. The National Universities Commission (NUC) should monitor the implementation of the policy statements. This is to ensure that libraries irrespective of ownership, gender and experience of the librarians, are encouraged and supported to implement the policy statements to a very high extent.

\section{References}

Association of Research Libraries (2016). Maintenance culture. Retrieved from http://old.arl.org/resources/pu bs/mmproceedings/smith.shtml.

Corrado, E.M. (2005). The importance of open access, open source and open standards for Libraries. Issues in Science, Technology Librarianship. Retrieved from Corrado@tenj.edu.

Darinson, G. U. (2013). The periodical collection. london: andre Deutsch.

Dye, T.R. (1984). - Understanding public policy. New Jersey: Englewood Cliffs.

Ezeh, V.C. (1997). Relationship between teacher's demographic variables and Classroom management. Unpublished M.Ed thesis, Rivers State University of Science and Technology, Port Harcourt.

Harbo, K., \& Hanson, V. T. (2012). Getting to know how library users need experimental ways to user - centered library innovation. LIBER Quarterly, $21,(3-4), 367-385$.

Heinz, W. \& Harold, K. (2005). Management - A global perspective. New Delhi: Tata McGraw-Hill Publishing Company Limited. 
Jennifer Ngozi B. Igwela, Walson and Ominini Brother Asako: Ownership,gender, and experience as correlates of policy implementation in the management of university libraries in the South-South, Nigeria

Ibukun, O.A. (2011). Principal leadership effectiveness, Regent University, International Journal of Leadership Studies, 6(2), 23-29.

Mattson, K. (2000). The librarian as secular minister to democracy: The life and ideas of John Cotton Dana. Libraries \& Culture, 35 (4), 514-534.

Meyer, S. (1997). Information and communication technology. Washington, DC: National Academic Press.

Muhammad, U.N. (2006). Preservation and conservation of library materials: The situation in the national Library of Nigeria. Nigerbiblios, $17(1 \& 2)$, $116-137$

National Universities Commission (1997). Manual on university management. Abuja: National Universities Commission.

Nok, G. (2006). The challenges of computerizing a university library in Nigeria: The case of Kashim Ibrahim Library, Ahmadu Bello University, Zaria. Library Philosophy and Practice, 8(2), 11-23.

Odukoya, D. (2012). Formulation and implementation of educational policies in Nigeria. ERNWACA, Faculty of Education, University of Lagos.

Okiy, R.B. (2005). Funding Nigerian Libraries in the $21^{\text {st }}$ century: will funding from alternative sources suffice? The Bottom line: Managing Library Finances, 18(2), 71-77.
Okorafor, C.N. (2006).Using library catalogue as access point to academic library collection in Nigeria. Nigerian Library and Information Science Trend, $(1 \& 2)$, 37-42.

Sule, J.G., Alinno, F. C. \&Ikwegbe, D. (2013). Rural economic development: Policy implementation in Nigeria. International Journal of Academic Research in Business and Social Sciences, 3(2), 62- 76.

Uduomoh, C.N. \& Okoro, C.C. (2007).The effect of library policy on overdue materials in university libraries in South- South Zone, Nigeria. Library Philosophy and Practice,2(2), 63-78.

Ugwu, S.C. (2000). Maintenance of administrative organization to enhance policy implementation in local government. A workshop paper on making policy and implementation techniques at local government level organized by global management consult.

Walson, O.B.A. (2015). Demographic and personality correlates of principals' performance in the management of secondary schools in South-south, Nigeria. Unpublished Ph.D Thesis, Faculty of Education, University of Nigeria, Nsukka. 